\title{
Assessment of Knowledge, Attitude, and Practice to Wards Hepatitis B Prevention Among Debre Tabor Health Science College Students, South Gondar, Amhara, Ethiopia 2021
}

Libsuye Yalgaw Zimamu ( $\sim$ libsuye@gmail.com )

DebreTabor Health Science College

Gashaw Mekete Adal

DebreTabor Health Science College

Bisrat Dessie Getu

DebreTabor Health Science College

Gashaw Mehiret Wubet

DebreTabor University

\section{Research Article}

Keywords: Awareness, knowledge, practices, hepatitis, virus, vaccination, students

Posted Date: December 20th, 2021

DOI: https://doi.org/10.21203/rs.3.rs-1185567/v1

License: (c) (i) This work is licensed under a Creative Commons Attribution 4.0 International License.

Read Full License 
ASSESSMENT OF KNOWLEDG, ATITUDE, AND PRACTICE TO WARDS

HEPATITIS B PREVENTION AMONG DEBRE TABOR HEALTH SCIENCE

COLLEGE STUDENTS, SOUTH GONDAR, AMHARA, ETHIOPIA 2021

Libsuye Yalgaw Zimamu (BSc)*1

${ }^{1}$ Department of Health Informatics, Debre tabor Health Science College, Debre tabor, Ethiopia;

Email: libsuye@gmail.com

Gashaw Mekete Adal (BSc, MSc) ${ }^{1}$

${ }^{1}$ Department of Nursing and child health, Debre tabor Health Science College, Debre tabor, Ethiopia.

Email: mulunehmekete@gmail.com

Bisrat Dessie Getu (BSc, MSc) ${ }^{1}$

${ }^{1}$ Department of Nursing and child health, Debre tabor Health Science College, Debre tabor, Ethiopia.

Email: edombsr10@gmail.com

Gashaw Mehiret Wubet (MD) ${ }^{2}$

${ }^{2}$ Debre tabor University, college of Health Science, Department of medicine, Debre tabor Ethiopia.

Email: mehiretg21stdr@gmail.com

*Corresponding author: Libsuye Yalgaw Zimamu (BSc)*1 Department of Health Informatics, Debre tabor Health Science College, Debre tabor, Ethiopia.

Email libsuye@gmail.com

Phone $+\mathbf{2 5 1 9 3 2 8 5 9 9 7 5}$

Authors:

LYZ (1ibsuye@gamil.com)

GMA (mulunehmekete@gmail.com)

BGD (edombsr10@gmail.com)

GMW (mehiretg21stdr@gmail.com) 


\section{ABSTRACT}

Background: Hepatitis B infection is caused by the hepatitis B virus which attacks the liver and can cause both acute and chronic disease and puts people at high risk of death from cirrhosis and liver cancer. Hepatitis B virus (HBV) is a highly contagious virus which is 50-100 times more infectious than HIV but have similar mode of transmission. Hepatitis B is the most common serious liver infection in the world. Hepatitis B infection is one of the major public health problems and is the tenth leading cause of death.

OBJECTIVES: The aim of this study is to assess knowledge, attitude, and practice towards hepatitis B prevention among students in Debre Tabor Health Science College.

METHODS: A cross-sectional study was conducted among 422 health science students in Debre tabor, town September to october,2021. The study participants were selected using a simple random sampling technique after proportionally allocating the sample size from the total number of students, and finally study subjects was selected by systematic random sampling based on their list studying at Debre tabor health science college. The data were collected by trained data collectors using a structured self-questionnaire. The collected data were checked, coded and entered to SPSS version 20, and for data cleaning and analysis.

RESULT: The response rate was $84.1 \%(n=355)$. A total of $262(73.8 \%)$ of the students knew about the transmission of HBV infection. Majority of the students (73.5\%) agreed for vaccination against $\mathrm{HBV}$ infection. About 10.4\%, 16.3\%, 5.6\%, 15.5\%, 10.4\%, 5.1\%, and $5.07 \%$ of were responds know wearing of gloves, wearing of goggles, adequate disposal of sharp materials, avoid patients diagnosed with hepatitis B, multivitamin/Blood Tonic, use antibiotics after contact, and other protective measures taken to protect against hepatitis B infection students knew about the preventive measures against HBV infection.

CONCLUSION: The overall awareness regarding HBV disease was found to be deficient among the health science students.

KEY WORDS: Awareness, knowledge, practices, hepatitis, virus, vaccination, students 


\section{INTRODUCTION}

\section{Background of the study}

Hepatitis B infection is a viral infection which is caused by the hepatitis B virus (HBV) that attacks the liver and can cause both acute and chronic disease (1). Hepatitis B infection is a potentially life-threatening blood born liver infection caused by hepatitis B virus (HBV) (2). $\mathrm{HBV}$ is concentrated most highly in blood with low concentration in certain body fluids, such as semen, vaginal secretions, and saliva, of persons infected with HBV (3). Person-to-person spread of HBV can occur among those living with someone chronically infected with hepatitis B (4). Knowledge, attitude, and practice (KAP) surveys are representative of a detailed population to collect information on what is known, believed and done in relation to a particular topic and are the most recurrently used study tool in health seeking behavior researches (6). These studies are the reflection of the important health related issues by the society and help to design prevention strategies (7). It is mainly spread by sexual contact with an infected person, sharing needles during injection drug use; occupational needle sticks or sharps exposure, or transmission from an infected mother to her baby during birth (5).

People at high risk include health care workers (HCWs) in contact with blood and human secretions, hemodialysis staff, oncology and chemotherapy nurses, all personnel at risk of needle stick/sharps injuries, which includes those working in operating rooms and clinical laboratories, respiratory therapists, surgeons, doctors, dentists, as well as medical, dental and nursing students (6). An exposure that might place health care professional at risk for HBV is defined as a percutaneous injury like a needle stick or cut with a sharp object or contact of mucous membrane or non-intact skin with blood, tissue, or other body fluids that are potentially infectious: cerebro spinal fluid (CSF), synovial fluid, pleural fluid, peritoneal fluid, pericardial fluid and amniotic fluid are also considered potentially infectious (8).

There is no specific treatment for acute hepatitis B (9). Care is aimed at maintaining comfort and adequate nutritional balance, including replacement of fluids that are lost from vomiting and diarrhea (10). The aims of treatment of chronic HBV infection are to achieve sustained suppression of HBV replication and to induce remission of liver disease before cirrhosis and hepatocellular carcinoma (HCC) develop (11). Several antiviral agents that were developed for the treatment of HIV infection proved to be effective in inhibiting HBV replication (12). 


\section{METHODSAND MATERIALS}

\section{Study area and period}

This study was conductedin Debre Tabor health science college from July to August 2021 G.C The Debre Tabor health science college established in 1982 and found in Debre Tabor Town, South Gondar zone, Northern Ethiopia. It is one of the established health science colleges in Amhara, Ethiopia located $667 \mathrm{~km}$ far from Addis Ababa, the capital of Ethiopia. The college has different health department like Health extension worker, comprehensive nursing, pharmacy, medical laboratory technology, anesthesia, environmental health and health informatics technician.

\section{Study design}

Institution based cross-sectional study design was conducted to assess knowledge, Attitude and Practice towards Hepatitis B viral infection among Debre Tabor health science students North West, Ethiopia

\section{Population}

\section{Source population}

The source population were all students in Debre Tabor health science students North West, Ethiopia 2021.

\section{Study population}

The study populations were those students of Debre Tabor Health Science College who will be select randomly.

\section{Eligibility criteria}

\section{Inclusion criteria}

Students studying in Debre Tabor Health Science, who were available during the data collection period.

\section{Exclusion criteria}

Students who had not be available during the data collection period for different reasons like due to illness.

\section{Sample size Determination}

The sample size is calculated using a formula for single population proportion considering the following assumptions.

Assumptions: With the assumptions of Confidence interval $=95 \%$, 
Using $n=Z \alpha / 2) 2 p(1-p) d 2$

Where, $\mathrm{n}=$ the required sample size

$\mathrm{Z} \alpha / 2=$ the standardized normal distribution curve value for the $95 \%$ confidence interval (1.96)

$\mathrm{P}=$ the level of KAP of students at woldiya university were $52 \% \mathrm{~d}=$ degree of precision (the margin of error between the sample and population, $5 \%)=0.05$

$\mathrm{n}=(1.96) 2(0.52(1-0.52)(0.52) \mathrm{n}=383.5 \approx 384$ by taking additional $10 \%$ contingency for nonresponse rate, the sample size was $\mathbf{=} \mathbf{4 2 2}$

\section{Sampling Technique}

Among the college department all seven department were included in this study. The study participants were been selected from each department as well as from each year by proportion to population size based on the total number of students in each department and systematic random sampling method was used to select specific student from the class room by using their list in the role sheet the first student was be selected by lottery method and the next respondent was selected in the calculated skip interval of the class. In case of absent students, the next student had taken as a respondent and the interval continue as in the previous. 


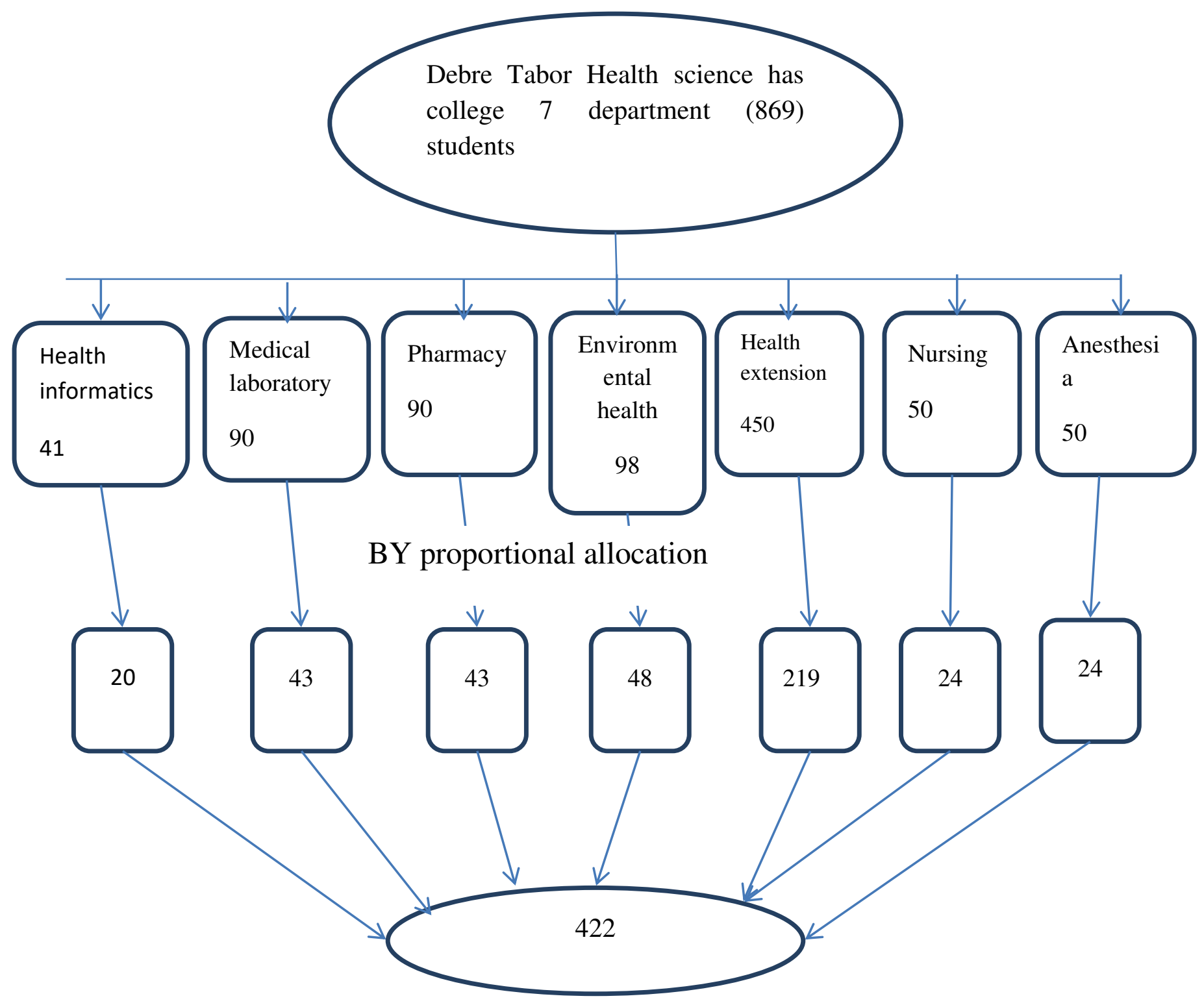

Figure 1: Schematic presentation of sampling procedure

\section{Data collection tool and procedure}

The data was collected from study subjects by Using pretested semi structures self-administered questionnaire. The questionnaire consisted thirty-five questions divided into four sections that cover questions to assess socio demographic characteristics, knowledge of respondents, Attitude of the respondents and practices of respondents. The questionnaire is adapted from researches done previously'. The questionnaire will be first developed in English and then translated to 
Amharic language version for appropriateness and easiness in approaching the study participants and back to English by language experts to check its consistency of meaning.

\section{Study Variables}

$>$ Knowledge

$>$ Attitude

$>$ Practice

\section{Operational definitions}

Good Knowledge: Refers for those study participants who answer more than half of knowledge questions correctly (25).

Poor knowledge: Refers for those study participants who answer half and less than half of knowledge questions correctly (25).

Good Attitude: Refers to those study participants who scored point greater than the mean score of attitude questions (25).

Poor Attitude: Refers to those study participants who scored point equal to and less than the mean of attitude questions (25).

Good Practice: Refers to those study participants who correctly respond to practice questions and score above the median value (25).

Poor Practice: Refers to those study participants who correctly respond to practice questions and score median value and below median value (25).

\section{Data quality assurance}

To assure data quality, three data collectors and one supervisor who can read and speak the local language fluently have trained for one day by the principal investigator before starting the actual data collection. Before starting the actual data collection, the tool was be pre-tested on $5 \%$ on Debre Tabor University. Collected data was checked for completeness and consistency by supervisors and principal investigator at the end of each day.

\section{Data Processing \& Analysis}

Data was entered to Epi-Info version 7 and then export to the SPSS software version 20 to be analyzed. Descriptive statistics was carried out to illustrate the means, standard deviations, and frequencies of the demographic profile of the respondents and magnitude KAP on Hepatitis B virus. 


\section{Ethical Consideration}

Ethical clearance was obtained from CBE office of College of Health Science, Debre Tabor University before conducting the study. Autonomy was insured by explaining the aims and objectives of the study to the students beforehand, and informing them that if they do not want to take part in the study they do not have to, and that this non-participation had no bearing on their grades. Confidentiality was ensured since the participants were anonymous. A statement is included at the top of the questionnaire, requesting students not to include identification, and that by completing the questionnaire and handing it in, they are consenting to take part in the study. 


\section{RESULT}

\section{Socio-demographic characteristics of the respondents}

Out of the 422 Debre tabor health science students sampled, 355 responded to the survey. This represents a response rate of $84.1 \%$. Majority of the respondent, 223 (62.8\%) were females. $256(72.1 \%)$ of them were aged less than equal to 25 years and the median age of 22 years. $69.3 \%$ of them had orthodox follower. Majority 168(47.3\%) of them were second year students. (Table 1)

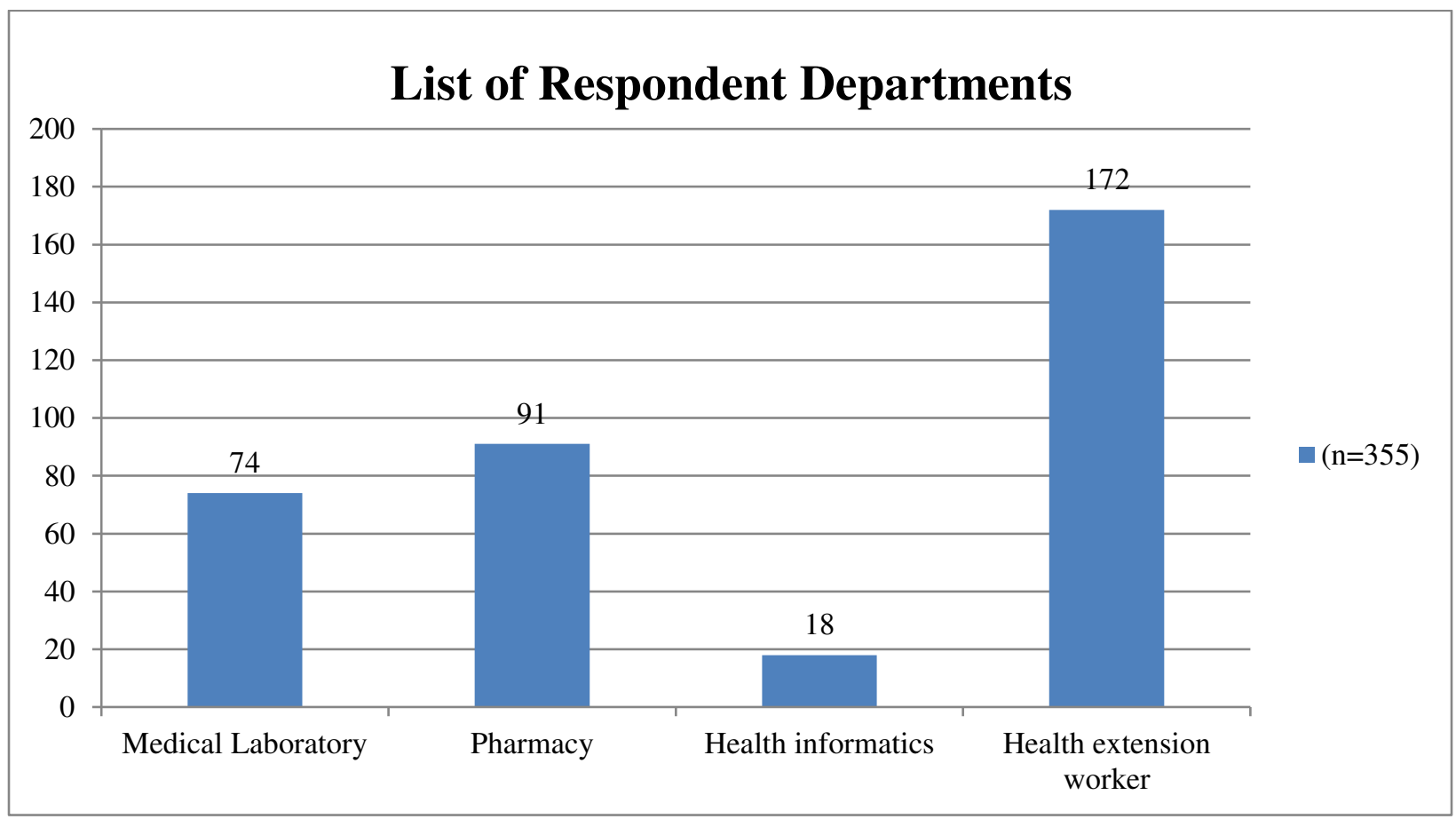

Figure 2:Name of departments were a study conducted from Debre tabor health science college. 
Table 1: Socio-demographic characteristics of the Study participants

\begin{tabular}{|c|c|c|c|}
\hline Variables & Categories & $(n=355$ & $\%$ \\
\hline \multirow[t]{2}{*}{ Gender } & Male & 223 & $62.8 \%$ \\
\hline & Female & 132 & $37.2 \%$ \\
\hline \multirow[t]{2}{*}{ Age } & $20-25$ & 256 & $72.1 \%$ \\
\hline & $26-30$ & 99 & $27.9 \%$ \\
\hline \multirow[t]{3}{*}{ Religion } & Orthodox & 246 & $69.3 \%$ \\
\hline & Muslim & 91 & $25.6 \%$ \\
\hline & Protestant & 18 & $5.1 \%$ \\
\hline \multirow[t]{3}{*}{ Year of study } & $1^{\text {st }}$ year & 111 & $31.3 \%$ \\
\hline & $2^{\text {nd }}$ year & 168 & $47.3 \%$ \\
\hline & $3^{\text {rd }}$ year & 76 & $21.4 \%$ \\
\hline \multirow[t]{4}{*}{ Department } & Medical Laboratory & 74 & $20.8 \%$ \\
\hline & Pharmacy & 91 & $25.6 \%$ \\
\hline & Health informatics & 18 & $5.1 \%$ \\
\hline & Health extension worker & 172 & $28.5 \%$ \\
\hline
\end{tabular}

\section{Respondents Knowledge on hepatitis B infection}

A total of 355 (84.1\%) of students have 298(83.9\%) of them were heard of hepatitis B disease before, and 149(42\%) of students know or got information about hepatitis B is during seminar and lecturing class. Regarding the report of students that, 150(42.3\%), and 262(73.8\%) of students were know correctly which hepatitis B is affects liver, and there is a higher risk of Hepatitis B than HIV transmission through needle stick injury respectively. Additionally, more than half of the respondents 204(57.5\%) were shows the symptoms of hepatitis B viral infection appear within few days always after the entrance of Hepatitis B virus to the body. 
A total of $149(42 \%)$ students knew that hepatitis B infection rout of transition can be through Needles and sharps injury. but, $279(78.6 \%)$ of students were reported that vaccination is the bast ways of prevention mechanism of hepatitis B infection. (Table2).

Table 2: Responses knowledge on Hepatitis B infection

\begin{tabular}{|c|c|c|c|}
\hline Variable & Categories & $(n=355$ & $\%$ \\
\hline \multirow{2}{*}{$\begin{array}{l}\text { Do you hear information about Hepatitis B } \\
\text { before }\end{array}$} & Yes & 298 & $83.9 \%$ \\
\hline & No & 57 & $16.1 \%$ \\
\hline \multirow[t]{3}{*}{ Where did you hear about Hepatitis B? } & Lectures and seminars & 149 & $42 \%$ \\
\hline & Media & 131 & $36.9 \%$ \\
\hline & Family and friends & 74 & $21.1 \%$ \\
\hline \multirow[t]{5}{*}{ Which organ does Hepatitis B affects? } & Liver & 150 & $42.3 \%$ \\
\hline & Heart & 18 & $5.1 \%$ \\
\hline & Kidneys & 19 & $5.4 \%$ \\
\hline & Brain & 38 & $10.7 \%$ \\
\hline & Not sure & 130 & $36.6 \%$ \\
\hline \multirow{2}{*}{$\begin{array}{l}\text { Symptoms of hepatitis B viral infection appear } \\
\text { within few days after the entrance of Hepatitis B } \\
\text { virus to the body }\end{array}$} & Yes & 204 & $57.5 \%$ \\
\hline & No & 151 & $42.5 \%$ \\
\hline \multirow[t]{3}{*}{ Route of transmission of Hepatitis B infection } & Blood and blood products & 56 & $15.8 \%$ \\
\hline & Needles and sharps injury & 149 & $42 \%$ \\
\hline & Sexual intercourse & 150 & $42.3 \%$ \\
\hline \multirow{2}{*}{$\begin{array}{l}\text { Higher risk of Hepatitis } B \text { than } \text { HIV } \\
\text { transmission through needle stick injury. }\end{array}$} & Yes & 262 & $73.8 \%$ \\
\hline & No & 93 & $26.2 \%$ \\
\hline \multirow[t]{2}{*}{ Preventing Hepatitis B infection can be through } & Vaccination & 279 & $78.6 \%$ \\
\hline & Practicing standard working & 76 & $21.4 \%$ \\
\hline $\begin{array}{l}\text { Hepatitis } B \text { vaccine prevent the disease } \\
\text { effectively }\end{array}$ & Yes & 355 & $100 \%$ \\
\hline \multirow[t]{3}{*}{ How many doses of hepatitis vaccine are there } & One dose & 92 & $25.9 \%$ \\
\hline & Two doses & 92 & $25.9 \%$ \\
\hline & Three doses & 171 & $48.2 \%$ \\
\hline
\end{tabular}




\begin{tabular}{|l|l|l|l|}
\hline Expected Interval between last dose and dose & $<6$ months & 93 & $26.2 \%$ \\
\cline { 2 - 4 } \multirow{2}{*}{\begin{tabular}{l} 
preceding it \\
\cline { 2 - 4 }
\end{tabular}} & $\geq 6$ months & 148 & $41.7 \%$ \\
\cline { 2 - 4 } & I don't know & 144 & $32.1 \%$ \\
\hline
\end{tabular}

\section{Respondents Attitude on hepatitis B infection}

From a total of 355 study participants, $242(68.2 \%)$ of where they believe that their job is high risk of acquiring Hepatitis B virus, and also, they believe that 243(68.5\%) of it were think hepatitis B vaccine costs too much costly.

On half of the study subjects 188(53\%) were agree on protection against Hepatitis B viral infection, and $261(73.5 \%)$ of it essential to receive vaccine.

Additionally, 280(78.9\%) of students respond that no need of or not have the special skills to effectively and safely care patients with Hepatitis B infection.

Majority of respondents report that 266(63.7\%) of agree on following infection control guidelines will protect you from being infected with Hepatitis B infection.

On the other hand, 207 (58.3\%) of them were not accept health professionals who are Hepatitis B virus positive should not give health care services to patients.

Table 3: Responses Attitude toward Hepatitis B infection

\begin{tabular}{|c|c|c|c|}
\hline Variable & Categories & $(n=355)$ & $\%$ \\
\hline \multirow{2}{*}{$\begin{array}{l}\text { Your job puts you at a high risk of acquiring Hepatitis } \\
\text { B virus? }\end{array}$} & Yes & 242 & $68.2 \%$ \\
\hline & No & 113 & $31.8 \%$ \\
\hline \multirow[t]{2}{*}{ Do you think hepatitis B vaccine costs too much? } & Yes & 243 & $68.5 \%$ \\
\hline & No & 112 & $31.5 \%$ \\
\hline \multirow{3}{*}{$\begin{array}{l}\text { You are in need of protection against Hepatitis B viral } \\
\text { infection? }\end{array}$} & Agree & 188 & $53 \%$ \\
\hline & Disagree & 112 & $31.5 \%$ \\
\hline & I don't have idea & 55 & $15.5 \%$ \\
\hline \multirow{2}{*}{ Do you consider it necessary to receive vaccine? } & Yes & 261 & $73.5 \%$ \\
\hline & No & 94 & $26.5 \%$ \\
\hline \multirow{2}{*}{$\begin{array}{l}\text { Do you think that health professionals who are } \\
\text { Hepatitis B virus positive should not give health care } \\
\text { services to patients? }\end{array}$} & Yes & 148 & $41.7 \%$ \\
\hline & No & 207 & $58.3 \%$ \\
\hline \multirow{2}{*}{$\begin{array}{l}\text { Do you feel that you do not have the skills needed to } \\
\text { effectively and safely care patients with Hepatitis B? }\end{array}$} & Yes & 280 & $78.9 \%$ \\
\hline & No & 75 & $21.1 \%$ \\
\hline
\end{tabular}




\begin{tabular}{|l|l|l|l|}
\hline \multirow{2}{*}{$\begin{array}{l}\text { Do you want not serve people with Hepatitis B in your } \\
\text { clinical attachment? }\end{array}$} & Yes & 56 & $15.8 \%$ \\
\cline { 2 - 4 } & No & 299 & $84.2 \%$ \\
\hline \multirow{2}{*}{ Testing outpatients for Hepatitis B is not necessary } & Agree & 279 & $78.6 \%$ \\
\cline { 2 - 4 } & Disagree & 57 & $16.1 \%$ \\
\cline { 2 - 4 } & Don't have idea & 19 & $5.4 \%$ \\
\hline $\begin{array}{l}\text { Following infection control guidelines will protect you } \\
\text { from being infected with Hepatitis B }\end{array}$ & Agree & 266 & 63.7 \\
\cline { 2 - 4 } & Disagree & 129 & 36.3 \\
\hline
\end{tabular}

\section{Respondents practice on hepatitis B infection}

Regarding to assess the practice of Debre tabor health science students were 340(80.5\%), and $355(100 \%)$ of students were ever tested for hepatitis B virus and not ever received hepatitis B Vaccine respectively they are not receiving as well as completing any dose of hepatitis vaccination.

From total respondents were $280(78.9 \%)$ of reports no specific pharmaceutical treatment available to cure hepatitis B infection 261(73.5\%) of consider it necessary to receive vaccine. Basically, respondents report $10.4 \%, 16.3 \%, 5.6 \%, 15.5 \%, 10.4 \%, 5.1 \%$, and $5.07 \%$ of were responds that wearing of gloves, wearing of goggles, adequate disposal of sharp materials, avoid patients diagnosed with hepatitis B, multivitamin/Blood Tonic, use antibiotics after contact, and other protective measures taken to protect against hepatitis B infection (Table4). 


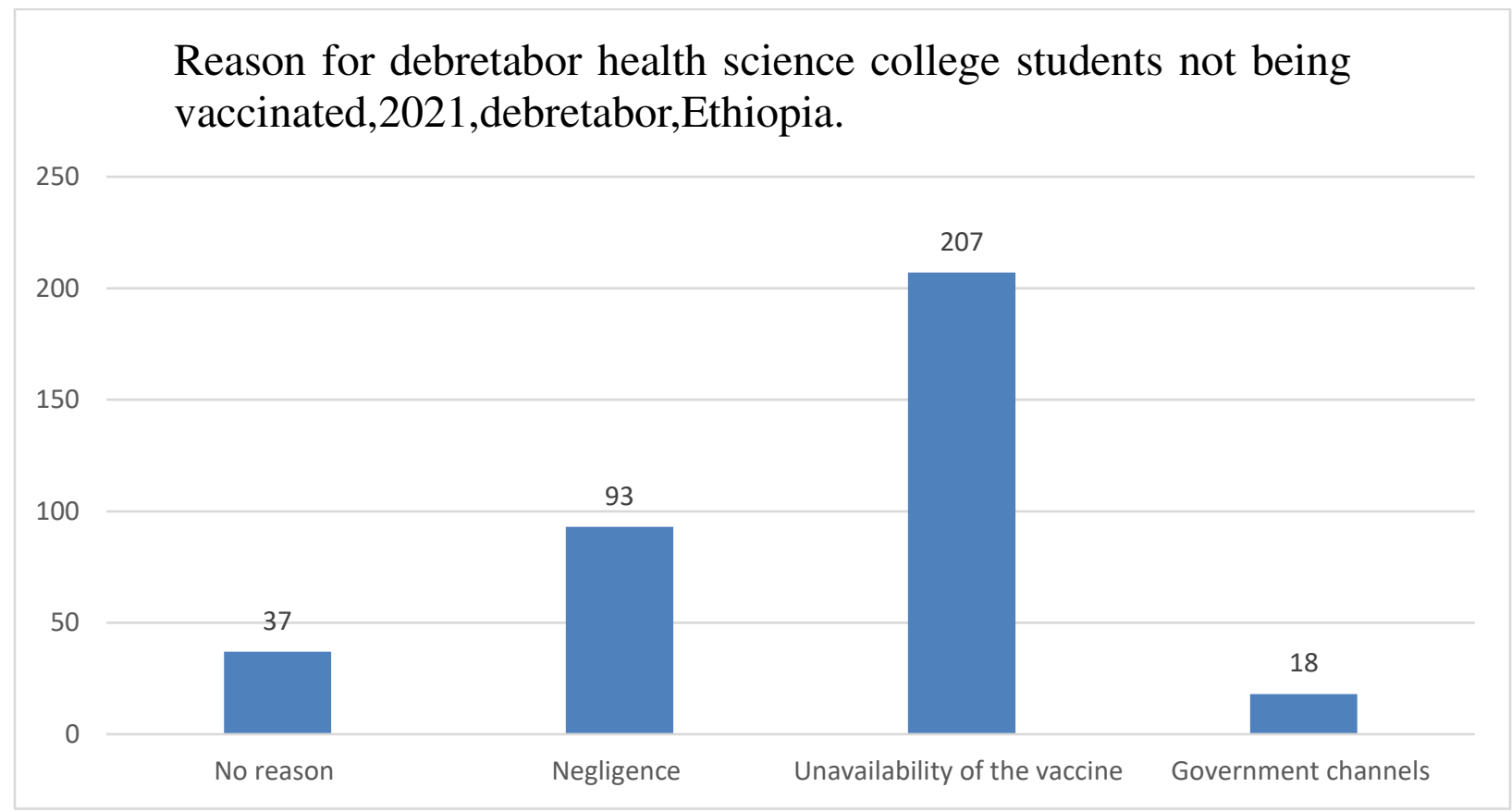

Figure 3:Reason for students not being Vaccinated

Table 4:5 Respondent's practice on hepatitis B infection

\begin{tabular}{|c|c|c|c|}
\hline Variable & Categories & $\begin{array}{l}(n=35 \\
5\end{array}$ & $\%$ \\
\hline \multirow{7}{*}{$\begin{array}{l}\text { Measures taken to protect against hepatitis B } \\
\text { infection }\end{array}$} & Wearing of gloves & 37 & $10.4 \%$ \\
\hline & Wearing of goggles & 58 & $16.3 \%$ \\
\hline & Adequate disposal of sharp materials & 20 & $5.6 \%$ \\
\hline & $\begin{array}{l}\text { Avoid patients diagnosed with } \\
\text { hepatitis B }\end{array}$ & 130 & $15.5 \%$ \\
\hline & Multivitamin/blood tonic & 55 & $10.4 \%$ \\
\hline & Use antibiotics after contact & 37 & $5.1 \%$ \\
\hline & Other & 18 & $5.07 \%$ \\
\hline \multirow[t]{2}{*}{ Have you ever tested for hepatitis B virus? } & Yes & 19 & $5.4 \%$ \\
\hline & No & 340 & $80.5 \%$ \\
\hline Have you ever received hepatitis B Vaccine? & No & 355 & $100 \%$ \\
\hline
\end{tabular}




\section{DISCUSSION}

The current study shows out of the 422 Debre tabor health science students sampled, 355 responded to the survey. This represents a response rate of $84.1 \%$. Majority of the respondent, $223(62.8 \%)$ were females. $256(72.1 \%)$ of them were aged less than equal to 25 years and the median age of 22 years. $69.3 \%$ of them had orthodox follower. Majority 168(47.3\%) of them were second year students.

A total of $355(84.1 \%)$ of students have 298(83.9\%) of them were heard of hepatitis B disease before, and 149(42\%) of students know or got information about hepatitis B is during seminar and lecturing class. Regarding the report of students that, 150(42.3\%), and 262(73.8\%) of students were know correctly which hepatitis B is affects liver, and there is a higher risk of Hepatitis B than HIV transmission through needle stick injury respectively. Additionally, more than half of the respondents 204(57.5\%) were shows the symptoms of hepatitis B viral infection appear within few days always after the entrance of Hepatitis B virus to the body.

Institution based cross-sectional observational study conducted in Teresina, Brazil to assess Knowledge about hepatitis B, Vaccine Situation of Students of a Public University mentioned that almost all $(98.9 \%)$ of the respondents have heard or know about hepatitis B. Ninety seven point two percent $(97.2 \%)$ of the respondents know that there is a vaccine against the disease, 1.1 $\%$ and $1.7 \%$ of the students say no about the availability of vaccine and don't know about the availability respectively. Among those respondents who knows the availability of HBV vaccine most of them $(87.4 \%)$ says there is three dose of complete HBV vaccine. Seventy-nine-point nine percent $(79.9 \%)$ of dentistry students were received hepatitis B vaccine, among them $62.2 \%$ were fully vaccinated, those who didn't take and have no idea whether they take or not were 9.5\% and $10.6 \%$ respectively. Forgetfulness was the most frequently answered reason for not receiving $\mathrm{HBV}$ vaccine $(50 \%)$ and the least frequently answered reason were lack of interest $5.6 \%(25)$.

Study done in Haramaya University, Ethiopia on the assessment of knowledge and practice towards Hepatitis B among Medical and Health Science students, out of the 322 participants, $43.8 \%$ were within the poor knowledge range whereas $56.2 \%$ showed adequate knowledge about HB (26).Another cross sectional study done in Northwest Ethiopia, Bahir Dar City Administration on Hepatitis B vaccine knowledge and vaccination status among health care workers on Knowledge of HCWs about hepatitis B infection, About 52\% of the respondents 
scored above the mean knowledge score about hepatitis B infection. Similarly, about $82 \%$ agreed that hepatitis B infection is more common in Sub Saharan Africa.

From the current study a total of 355 study participants, 242(68.2\%) of where they believe that their job is high risk of acquiring Hepatitis B virus, and also, they believe that 243(68.5\%) of it were think hepatitis B vaccine costs too much costing half of the study subjects $188(53 \%)$ were agree on protection against Hepatitis B viral infection, and 261(73.5\%) of it essential to receive vaccine. Additionally, 280(78.9\%) of students respond that no need of or not have the special skills to effectively and safely care patients with Hepatitis B infection. Majority of respondents report that $266(63.7 \%$ ) of agree on following infection control guidelines will protect you from being infected with Hepatitis B infection the other hand, 207 (58.3\%) of them were not accept health professionals who are Hepatitis B virus positive should not give health care services to patients.

Study done in Pakistan among healthy population the overall respondents had a negative attitude towards Hepatitis B with mean score of $3.72 \pm 1.2$ Majority of the respondent $(79.7 \%)$ believed that they cannot get infected with $\mathrm{HB},(39.5 \%)$ respondents stated that they will be a shamed to get infected with HB (26.0\%) agreed to consult a physician as their first choice of treatment (28). Also, in another study done in Pakistan among hepatitis B patients, out of the $390 \mathrm{HB}$ patients, $79.2 \%$ were within the negative attitude range whereas $20.8 \%$ showed appositive attitude towards HB. Similar study done in Ghana on knowledge, attitude and practices concerning Hepatitis B infection, among healthcare workers shows that out of the 175 study participants, 2.28-25.13\% were within the negative attitude range whereas 69.14-91.9\% showed a positive attitude towards HBV whereas 4.57-5.7\% were unaware of the issues (29).

Regarding to assess the practice of Debre tabor health science students were $340(80.5 \%)$, and $355(100 \%)$ of students were ever tested for hepatitis B virus and not ever received hepatitis B Vaccine respectively they are not receiving as well as completing any dose of hepatitis vaccination.

From total respondents were $280(78.9 \%)$ of reports no specific pharmaceutical treatment available to cure hepatitis B infraction 261(73.5\%) of consider it necessary to receive vaccine. Basically, respondents report $10.4 \%, 16.3 \%, 5.6 \%, 15.5 \%, 10.4 \%, 5.1 \%$, and $5.07 \%$ of were responds that wearing of gloves, wearing of goggles, adequate disposal of sharp materials, avoid 
patients diagnosed with hepatitis B, multivitamin/Blood Tonic, use antibiotics after contact, and other protective measures taken to protect against hepatitis B infection

Hepatitis B and Liver Cancer knowledge and preventive Practices among Asian Americans in the San Francisco Bay Area, California found that sixty percent of adults reported having been tested for hepatitis B, 31\% reported having been vaccinated against hepatitis $\mathrm{B}$, had never been vaccinated against hepatitis B, had never been screened for liver cancer, or had not had their children vaccinated against hepatitis B were significantly less likely to have been tested for hepatitis (30).

Study in Quetta, Pakistan found $66.9 \%$ of patients were within the bad practice range whereas $33.1 \%$ showed good preventive practice towards HB. The majority of the patients $(98.2 \%)$ had never had HB screening before they became infected. The mean score for related practices was $2.37 \pm 1.0$ revealing poor practices among study participants. In another similar study among healthy population of Quetta, Pakistan Majority of the respondents 96.9\% never went for HB screening and $86.8 \%$ stated a negative immunized status against $\mathrm{HB}$. The mean score for $\mathrm{HB}$ related practices was $2.76 \pm 1.1$ revealing poor practices among the study participants (26).

Study done in haramaya Ethiopia reveal that the majority of the respondents, $(85.7 \%)$ never screened for $\mathrm{HB}$ and $86.6 \%$ stated a negative immunized status against HB. The mean score for HB related practices was $2.04 \pm 1.15$ revealing poor practices among the study participants $13.4 \%$ were vaccinated against HBV (19). Similar study done in North West Ethiopia found practical measures for HBV prevention and Health seeking behavior of the 246 participants, only $9.3 \%$ had screened for HBV, $4.9 \%$ students had vaccinated against HBV. Overall, there were poor practical measures on prevention of HBV infection among the study subjects (32). 


\section{Conclusion}

This study concludes that the first- and second-year health science students lack awareness about the hazards of HBV infection. Moreover, not all the health science students were vaccinated against hepatitis $\mathrm{B}$, which makes them more prone to $\mathrm{HBV}$ infection. As the students have an increased risk of acquiring injuries while performing at hospital involving blood and saliva.

It is recommended that a policy be made, under which health education and complete vaccination of all the health science students with regard to HBV infection be made mandatory in the first year itself.

\section{Competing interests}

The authors report no conflicts of interest

Funding: This research didn't receive any grants from any funding agency in the public, commercial, or not-for-profit sectors.

\section{Authors' contributions}

Libsuye Yalgaw Zimamu, Principal Investigator

Gashaw Mekete Adal, Bisrat Dessie Getu, and Dr. Gashaw Mehiret Wubet Technical Support in Data Collection and Analysis

\section{Acknowledgements}

First, I would like to express our gratitude for Deb tabor university, school of medicine and health science for providing this opportunity to develop thesis report and allowing to undertake my area of interest. 


\section{REFERENCE}

1. Lavanchy D. 2004. Hepatitis B virus epidemiology, disease burden, treatment, arid current and emerging prevention and control measures. Journal of Viral Hepatitis vol. 11, no. 2: pp 97-107.

2. Wiersma S. 2009. Scaling up Global Access to Hepatitis B Vaccine. 5th IAS Conference on HIV Treatment, Pathogenesis and Prevention, Cape Town, abstract WeBS 102.

3. Department of Health and Human service Center for Disease Control and Prevention. December 8, 2006.A Comprehensive Immunization Strategy to Eliminate Transmission of Hepatitis B Virus Infection in the United States. Vol. 55: No. RR-16.

4. Communicable Disease Control. April 2009. New Hampshire Department of Health and Human Services. pp 10.

5. Smelzer SC and Bare B. 2003. Brunner and Suddarth's Textbook of medical surgical nursing.10th edition.

6. Centers for Disease Control and Prevention. 2001. Updated U.S Public health service guidelines for the management of occupational exposures to HBV, HCV, and HIV and75 recommendations for post exposure prophylaxis. MMWR 50: RR-11.

7. Doctor KedirYimerSeid. 2005. Serological and Molecular Characterization of Hepatitis B, C and D Viruses Infections among Health Professionals in RasDesta and TikurAnbessa Hospitals, Addis Ababa, Ethiopia.

8. Zajac BA, West DJ, McAleer WJ, Scolnick EM. 1986. Overview of clinical studies with hepatitis B vaccine made by recombinant DNA. Journal of Infect vol 13: pp 39-45. 1

9. Banatvala J E, Van Damme P. 2003. Hepatitis B vaccine - do we need boosters. J Viral Hepatvol 10: pp 1-6.

10. Sridhar MR, Boopathi S, Lodha R, Kabra SK. 2004. Standard precautions and postexposure prophylaxis for preventing infections. Indian J Pediatrvol 71: pp 617-25.

11. Catalani C, Biggeri A, Gottard A, Benvenuti M, Frati E, Cechini C. 2004. Prevalence of $\mathrm{HCV}$ infection among health care workers in a hospital in central Italy. Eur J Epidemiolvol 19: pp 73-7.59

12. Canini SR, Gir E, Hayashida M, Machado AA. 2002. Needle stick injuries among nursing workers at a university hospital in the interior of the Sao Paulo state. Rev Lat Am Enfermagemvol 10: pp172-178. 
13. West DJ. (1984). The Risk of Hepatitis B infection among Health Professionals in the United States: A Review. Am J Med Scivol 287: pp 26-33.

14. Sarrazin U, Brodt H, Sarrazin C, and Zeuzem S. 2005. 'Prophylaxegegen"uber HBV, HCV und HIV nachberuflicher Exposition'. DeutschesArzteblatt, vol 102, no. 33, pp 2234 - 2239.

15. Tetali S, Choudhury PL. 2006. Occupational exposure to sharps and splash risk among health care providers in three tertiary care hospitals in South India. Indian J Occup Environ Med vol 10: pp 35-40.

16. Smith DR, Leggat PA. 2005.Needlestick and sharps injuries among nursing students. J AdvNursvol 5: pp 449-55.

17. Ghahramani F, Mohammadbeigi A and Mohammadsalehi N. 2006. A survey of the students' knowledge about hepatitis. Hepat Mon vol 6: pp 59-62.

18. Blumberg BS, Alter HJ, Visnich S. 1965. A “new” antigen in leukemia sera. JAMA vol 191: pp 541-546.

19. Glanz, K., Rimer, B.K. \& Lewis, F.M. 2002. Health behavior and health education theory, research, and practice. 3 rd ed. San Francisco: Jossey-Bass.

20. Dunford L., Carr M.J., Dean J., Nguyen L.T., Ta T.T.H., Nguyen, B.T., Connell J., Coughlan, S. Nguyen, H.T. Hall, W.W. \& Nguyen T.L.A. 2012. A multicentre molecular analysis of hepatitis B and blood-borne virus co-infections in VietNam. PLoS ONE 7(6). doi:10.1371/ journal. pone.0039027.

21. Hepatitis B Foundation. - Statistics. Available at: http://www.hepb.org/hepb/statistics.htm

22. McMahon BJ. 2005. Epidemiology and natural history of hepatitis B. Semin Liver Dis vol 25: pp 3-8.

23. Margolis HS, Alter MJ, Hadler SC. 1991. Hepatitis B: evolving epidemiology and implications for control. Semin Liver Dis vol 11: pp 84- 92.

24. World Health Organization. 1983. Prevention of liver cancer, Report of a WHO Meeting, WHO Tech Rep Ser; vol 691: pp 8-9.

25. Dr C F Kiire. 1996. The epidemiology and prophylaxis of hepatitis B in sub-Saharan Africa: a view from tropical and subtropical Africa.60

26. Tsega E. 2000. Epidemiology, prevention and treatment of viral hepatitis with emphasis on new developments. Ethiop Med J vol 38: pp 131-141 
27. Kefene H, Rapicetta M, Rossi GB, Bisanti L, Bekura D, Morace G, Palladino P, Di Rienzo A, Conti S, Bassani F. 1988. Ethiopian national hepatitis B study. J Med Virolvol 24: pp 7584.

28. Gebremeskel T, Beshah T, Tesfaye M, Beletew B, Mengesha A, Getie A. Assessment of knowledge and practice on hepatitis $\mathrm{B}$ infection prevention and associated factors among health science students in Woldia University, Northeast Ethiopia. Advances in preventive medicine. 2020 Apr 9;2020.

29. Abebe A, Nokes DJ, Dejene A, Enquselassie F, Messele T, Cut FT. (2003). Seroepidemiology of hepatitis B virus in Addis Ababa, Ethiopia: transmission patterns and vaccine control. Epidemiol Infect vol 131: pp 757-70.

30. Rahlenbeck SI, Yohannes G, Molla K, Reifen R, Assefa A. (1997). Infection with HIV,syphilis and hepatitis B in Ethiopia: a survey in blood donors. Int J STD AIDSvol 8: pp 261-264.

31. Tsega E, Nordenfelt E, Hansson BG, Mengesha B, Lindberg J. 1992. Chronic liver disease in Ethiopia: a clinical study with emphasis on identifying common causes. Ethiop Med J vol 30: pp 1-4 


\section{ANNEXES}

Annex I: Information Sheet

Section A: Socio-demographic characteristics of the respondent

\begin{tabular}{|c|c|c|c|c|}
\hline \multicolumn{5}{|c|}{ Part I: socio-demographic Characteristics } \\
\hline S. No & Question & \multicolumn{2}{|l|}{ Response } & Skip \\
\hline 101 & Gender & \multicolumn{2}{|l|}{$\begin{array}{ll}\text { 1. } & \text { Male } \\
\text { 2. } & \text { Female }\end{array}$} & \\
\hline 102 & Age & \multicolumn{2}{|c|}{ years } & \\
\hline 103 & Religion & $\begin{array}{ll}\text { 1. } & \text { Orthodox } \\
\text { 2. } & \text { Muslim } \\
\text { 3. } & \text { Protestant }\end{array}$ & $\begin{array}{l}\text { 4. Catholic } \\
\text { 5. Other }\end{array}$ & \\
\hline 104 & Year of study & \multicolumn{2}{|l|}{$\begin{array}{ll}\text { 1. } & 1^{\text {st }} \text { year } \\
2 . & 2^{\text {nd }} \text { year } \\
\text { 3. } & 3^{\text {rd }} \text { year }\end{array}$} & \\
\hline \multicolumn{2}{|r|}{ Department } & \multicolumn{2}{|c|}{$\begin{array}{ll}\text { 1. } & \text { Medical Laboratory } \\
\text { 2. } & \text { Pharmacy } \\
\text { 3. Environmental health } \\
\text { 4. Health informatics } \\
\text { 5. Health extension worker } \\
\text { 6. Anesthesia } \\
\text { 7. Comprehensive nursing }\end{array}$} & \\
\hline \multicolumn{5}{|c|}{ Part II: Section B: Respondents Knowledge about Hepatitis B infection } \\
\hline S. No & Question & \multicolumn{2}{|l|}{ Response } & Skip \\
\hline 201 & $\begin{array}{l}\text { Do you know or have you heard of } \\
\text { Hepatitis B? }\end{array}$ & \multicolumn{2}{|l|}{$\begin{array}{ll}\text { 1. } & \text { Yes } \\
\text { 2. } & \text { No }\end{array}$} & $\begin{array}{l}\mathrm{Go} \text { to } \mathrm{Q} \\
\mathrm{N} \underline{\mathrm{o}} 202\end{array}$ \\
\hline 202 & If you hear, from where did you hear & \multicolumn{2}{|c|}{$\begin{array}{l}\text { 1. Books and journal articles } \\
\text { 2. Lectures and seminars } \\
\text { 3. Media } \\
\text { 4. Family and friends } \\
\text { 5. Special workshops concerning HBV } \\
\text { 6. Other specify }\end{array}$} & \\
\hline 203 & $\begin{array}{l}\text { Which part of our organ does } \\
\text { Hepatitis B affects? }\end{array}$ & $\begin{array}{ll}\text { 1. } & \text { Liver } \\
\text { 2. Heart } \\
\text { 3. Kidneys } \\
\text { 4. Brain } \\
\text { 5. Not sure }\end{array}$ & & \\
\hline 204 & $\begin{array}{l}\text { The symptoms of hepatitis B viral } \\
\text { infection appear within few days } \\
\text { Always after the entrance of Hepatitis } \\
\text { B virus to the body? }\end{array}$ & $\begin{array}{ll}\text { 1. } & \text { Yes } \\
\text { 2. No } \\
\text { 3. I don }\end{array}$ & & \\
\hline
\end{tabular}




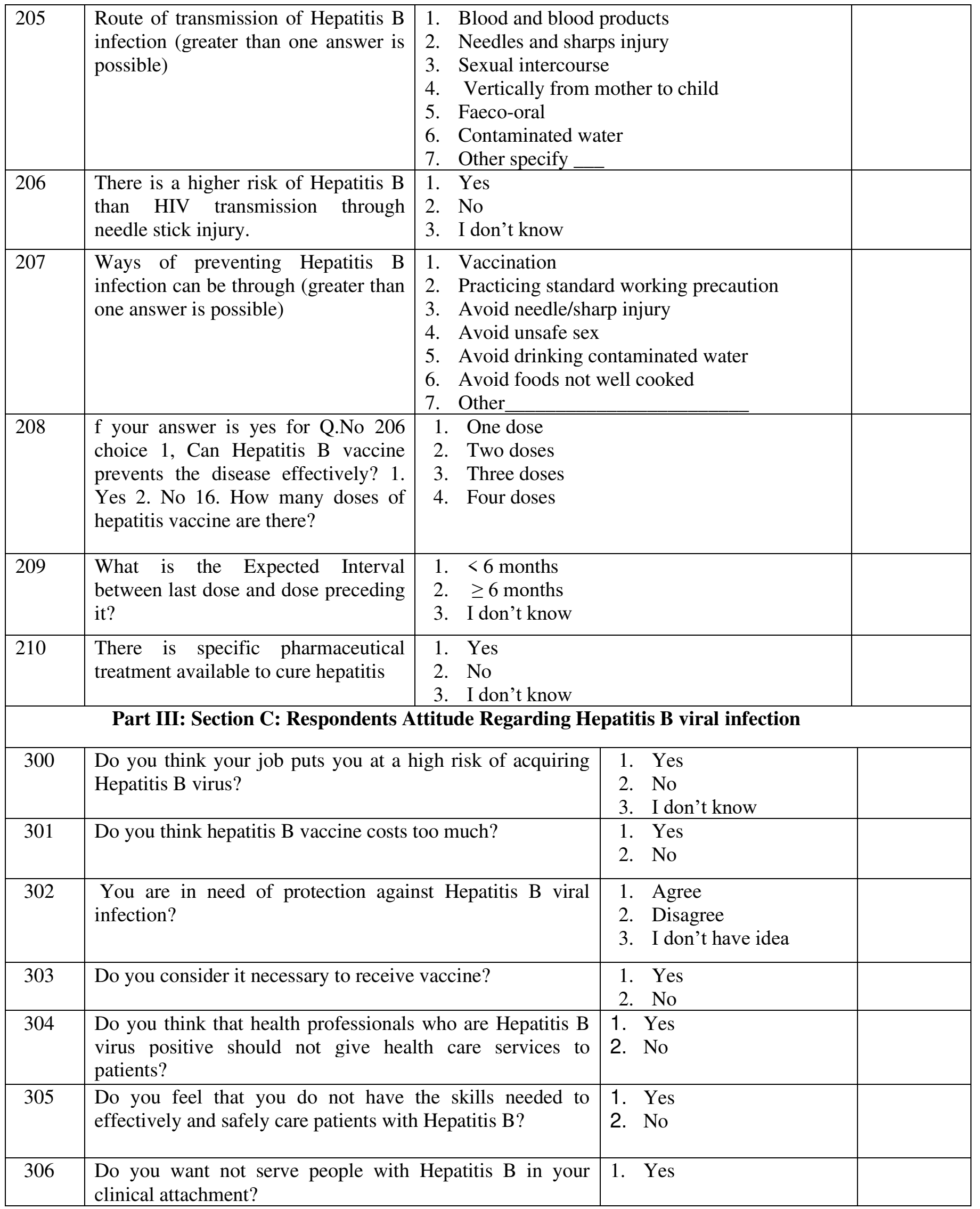




\begin{tabular}{|c|c|c|c|}
\hline & & 2. No & \\
\hline 307 & Testing outpatients for Hepatitis B is not necessary & $\begin{array}{ll}\text { 1. } & \text { Agree } \\
\text { 2. } & \text { Disagree } \\
\text { 3. } & \text { Don't have idea }\end{array}$ & \\
\hline 308 & \begin{tabular}{l|l} 
Following infection control guidelines will protect you from & 1 \\
being infected with Hepatitis B & 2 \\
& 3
\end{tabular} & $\begin{array}{ll}\text { 1. } & \text { Agree } \\
\text { 2. } & \text { Disagree } \\
\text { 3. } & \text { Don't have idea }\end{array}$ & \\
\hline \multicolumn{4}{|c|}{ Part Iv: Respondents Practice Regarding Hepatitis B viral infection } \\
\hline 400. & $\begin{array}{l}\text { Do you often use additional infection control precautions } \\
\text { when you caring for patients with Hepatitis B }\end{array}$ & \begin{tabular}{l|ll} 
is & Yes \\
& 2. & No
\end{tabular} & \\
\hline 401. & $\begin{array}{l}\text { Do you deliver the same standard of care to patients with } \\
\text { Hepatitis B as you do for other patients? }\end{array}$ & $\begin{array}{ll}\text { 1. } & \text { Yes } \\
\text { 2. } & \text { No }\end{array}$ & \\
\hline 402. & $\begin{array}{l}\text { Measures taken to protect against hepatitis } \mathrm{B} \text { infection } \\
\text { (more than one answer is possible) }\end{array}$ & $\begin{array}{ll}\text { 1. } & \text { Wearing of gloves } \\
\text { 2. } & \text { Wearing of goggles } \\
\text { 3. } & \text { Adequate disposal of } \\
& \text { sharp materials } \\
\text { 4. } & \text { Avoid patients } \\
& \text { diagnosed with } \\
& \text { hepatitis B } \\
\text { 5. } & \text { Multivitamin/Blood } \\
& \text { Tonic } \\
\text { 6. } & \text { Use antibiotics after } \\
\text { contact } \\
\text { 7. }\end{array}$ & \\
\hline 403. & Have you ever tested for hepatitis B virus? & $\begin{array}{ll}\text { 1. } & \text { Yes } \\
\text { 2. } & \text { No }\end{array}$ & \\
\hline 404. & $\begin{array}{l}\text { Have you ever received hepatitis B Vaccine? (If yes answer } \\
\text { question } 403\end{array}$ & $\begin{array}{ll}\text { 1. } & \text { Yes } \\
\text { 2. } & \text { No }\end{array}$ & $\begin{array}{l}\text { If no Go to } \\
\text { Q no } 405\end{array}$ \\
\hline 405. & $\begin{array}{l}\text { If "yes" for question number } 403 \text { Number of doses of } \\
\text { vaccine you received? }\end{array}$ & $\mid \begin{array}{ll}1 . & 1 \text { dose } \\
\text { 2. } & 2 \text { doses } \\
\text { 3. } & \geq 3 \text { doses }\end{array}$ & \\
\hline 406. & Do your complete vaccination schedule? & $\begin{array}{ll}\text { 1. } & \text { Yes } \\
\text { 2. } & \text { No } \\
\end{array}$ & \\
\hline 407. & $\begin{array}{l}\text { If "No" for question number 32, reason for not being } \\
\text { Vaccinated? }\end{array}$ & \begin{tabular}{|ll}
$\mathrm{g}$ & No reason \\
2. Negligence \\
3. I can't be infected \\
with hepatitis B \\
4. Unavailability of the \\
vaccine through \\
government channels \\
5. Unwilling to spend \\
time and money for \\
the vaccine \\
6. Fear of the side
\end{tabular} & \\
\hline
\end{tabular}




\begin{tabular}{|l|l|l|l|}
\hline & & $\begin{array}{l}\text { effect of the vaccine } \\
\text { Other } \\
\text { specify__ }\end{array}$ & \\
\hline
\end{tabular}

Thank you for your time! 